\title{
ASSESSING FACTORS AFFECTING THE REPAYMENT RATE OF MICROFINANCE INSTITUTIONS A Case Study of Village Credit Institutions of Gianyar, Bali
}

\author{
LincolinArsyad
}

This paper attempts to assess the influence of several factors on the repayment rate of the Village Credit Institutions (Lembaga Perkreditan Desa or simply LPDs) in Gianyar district in Bali. Using a quantitative approach (logistic model) the findings of this study indicate that the Balinese social custom, including social values, norms, and sanctions (informal institutions) have an influence on sustaining the high repayment rate of the LPDs. This finding conforms to the some previous studies using institutional approach that reveal the high repayment rate of the LPDs in Gianyar district is influenced by their institutional arrangement that based on custom regulation which includes social norms, sanctions, and involvement of custom village leader in screening process and contractual enforcement of loan (informal institutions), by regulations set up by the Central Bank (formal institutions), and by the mechanism of collecting loan repayments applied by the LPDs management.

Keywords: informal institutions; microfinance institutions; repayment rate 
Gadjah Mada International Journal of Business, May-August 2006, Vol. 8, No. 2

\section{Introduction}

The term microfinance refers to the provision of financial services (generally savings and credit) to low-income clients (ADB 2000; Ledgerwood 1999; Robinson 2001). The clients are often identified as traders, street vendors, small farmers, service providers (hairdressers, rickshaw drivers), and artisans and small producers, such as blacksmiths and seamstresses. In practice, however, in addition to financial intermediation, some microfinance institutions provide social intermediation services such as group formation, development of self-confidence, and training in financial literacy and management capabilities among members of a group intended to benefit lowincome women and men (Bennett 1998; Ledgerwood 1999). Part of the reasons is because low-income people face strong barriers (such as illiteracy, gender discrimination, and remoteness) in trying to gain access to ordinary financial service institutions (Ledgerwood 1999: 63). This means that the skills and confidence of lowincome people have to be developed in addition to credit provision. Therefore, the microfinance approach is not a minimalist approach offering only financial intermediation but an integrated approach offering both financial intermediation and other services mentioned above (Ledgerwood 1999: 65). It can also then be expected to reduce poverty and to develop and strengthen the institutional capacity of local financial systems through find- ing ways to cost-effectively lend money to poor households (Ledgerwood 1999; Morduch 1999; Morduch 2000; Otero 1999; Snow 1999).

Microfinance institutions are generally characterized by a collage of dynamic, innovative, and flexible arrangements tailored to the local economic and social environment (Adams and Fitchett 1992: 3). They argue that these arrangements are resilient and that many of them have grown over a long period. This flexibility is accorded by the limited regulation, along with small size, with most microfinance institutions operating in a circumscribed area, or in a specific niche of the market where personal knowledge of borrowers is possible (Ghate 1988). The type of transaction is small and short-term, which is based on personal relationships or the institution's intimate knowledge of its clientele (Wai 1992), and which usually occur close to where clients live, shop, or work. To facilitate the clients' entry, microfinance institutions also apply a simple application procedures, and loans are disbursed quickly (ADB 2000). The interest rates charged by microfinance institutions are market-oriented and intended to cover both their operational and financial costs, based on the assumption that the poor are willing to pay for access and convenience. To sum up, Wai argues that these arrangements are flexible, adapt to economic change, innovative, involve low transaction costs for both lender and borrower, and result in high loan recovery rates (Wai 1992: 340). 
Arsyad-Assessing Factors Affecting the Repayment Rate of Microfinance Institutions

As a lending institution, microfinance is a risky business because repayment of loans can seldom be fully guaranteed. The failure of a large number of microfinance institutions in many developing countries was due, among other things, to their inability to ensure good repayment rates among their borrowers (Adams 1984; Woolcock 1999; Yaron 1994). According to some authors (Christen 1998; Sharma and Zeller 1997; Woolcock 1999; Yaron 1994; Zeller 1998), the repayment rate is the most important performance indicators of microfinance institution. Woolcock (1999), for instance, points out that the most common measure of a microfinance program's performance is its loan repayment rate, since this has a large bearing on whether a program is likely to be financially sustainable. Yaron (1994) also emphasizes that a high profit earned by micro-finance institutions cannot be used as the only indicator of self-sustainability of the institutions, since a high profit could be attained only in the short period. Attaining a high rate of loan collection (repayment rate) is a necessary condition for a micro-finance institution to become self-sustainable in the long run. Loan losses often have been the largest cost borne by the institutions and the principal cause of insolvency and illiquidity. The importance of the portfolio quality indicator including the repayment rate is also reflected in the health criteria of banking institu- tion in Indonesia set up by the Central Bank -the so-called CAMEL criteria that gives a high weight of thirty percent for this indicator (Bank Indonesia 1997).

This paper attempts to assess the influence of several factors on the repayment rate of the Village Credit Institutions [Lembaga Perkreditan Desa (LPD)] in Gianyar district in Bali. The rationale in selecting LPDs in Gianyar as the case of this study is an explorative reason. An exploratory case $^{1}$ may be selected for the examination of a subject area on which there is little prior theory or evidence available (Scapens 1990: 272-273). Based on this perspective, the LPD case is an exploratory one since even though the LPD is considered to be a fully sustainable microfinance institution in Indonesia by some scholars (Chaves and Gonzales-Vega 1996; Christen et al. 1995), the LPD represents a microfinance institution little understood from the point of view of its sociocultural context, its management, and other factors influencing its performance.

The paper is structured as follows. Section 2 briefly discusses the development of the LPDs in Gianyar district in Bali and followed by a short description of their sociocultural environment. Section 4 presents the methodology and the results of analysis. Conclusions are presented in the last section.

${ }^{1}$ Yin uses the terms 'representative' or 'typical' case (see Yin 2003: 42) 
Gadjah Mada International Journal of Business, May-August 2006, Vol. 8, No. 2

The Development of LPD of Gianyar

The LPDs are community-based financial institutions (microfinance institutions) that are owned, managed and used by the members of the custom village (desa adat) in Bali (Government of Bali 1988). The first LPD was established in 1984 and many more followed in the following years. The objectives of establishing an $L P D$ in each custom village are to support rural economic development through enhancing savings behavior of rural people and providing credit for smallscale enterprise, to eliminate exploitative forms of credit relations, to create an equal opportunity for business activities at the village level, and to increase the degree of monetization in rural areas (Government of Bali 2002). These objectives reflect the development mission of the $L P D$ s to provide financial service for rural people in Bali.

In Gianyar district of Bali, the first Village Credit Institution (LPD) established was $L P D$ Manukaya, as one of $L P D$ pilot projects, located in

Table 1. General indicators of Village Credit Institutions (LPDs) within Gianyar District of Bali Province, 1999-2001

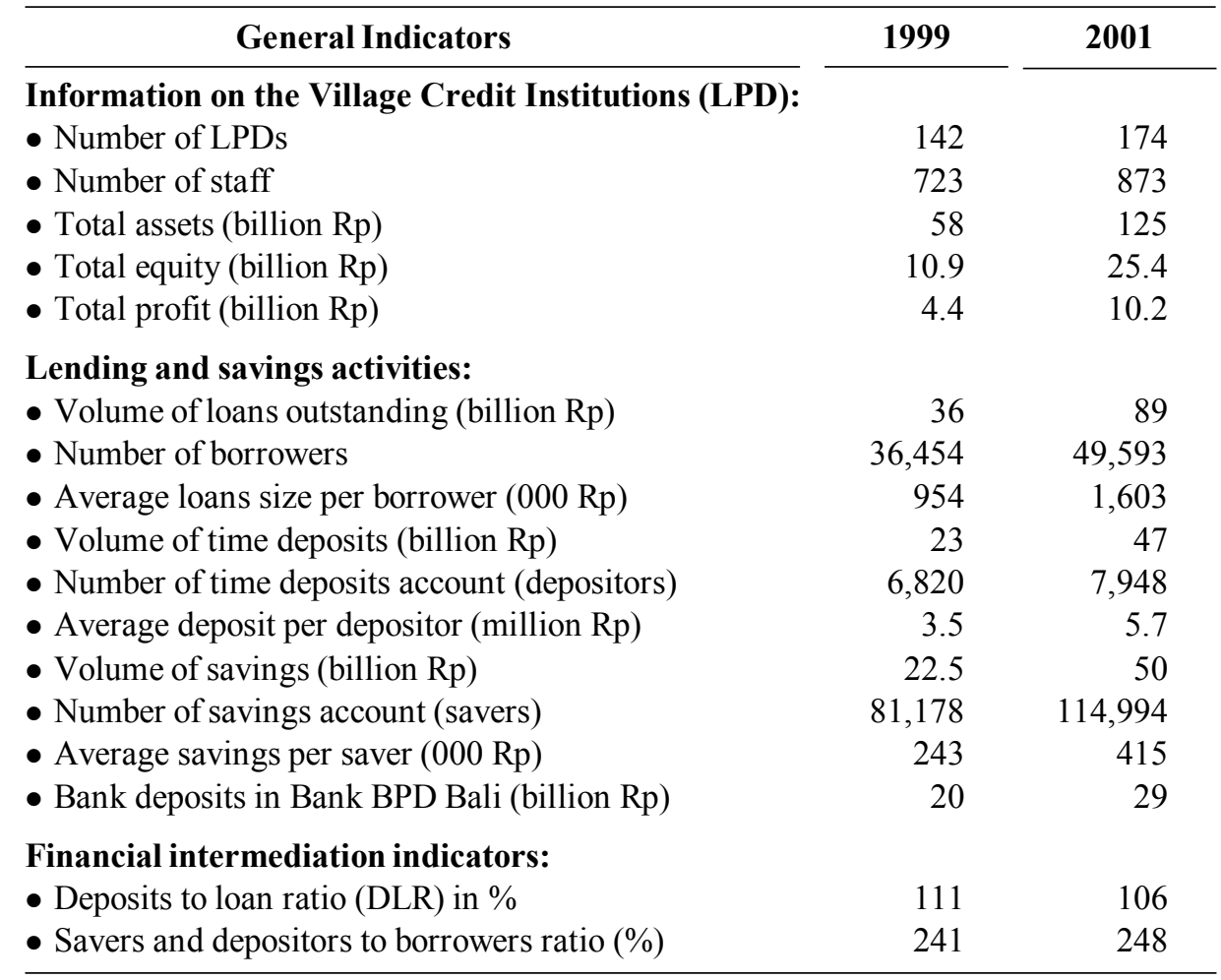

Source: PLPDK, Financial Report of LPD Gianyar District of Bali Province 1999 and 2001 (computed by the author). 
Arsyad-Assessing Factors Affecting the Repayment Rate of Microfinance Institutions

the custom village of Manukaya in 1984. Subsequently, the growth of $L P D$ in Gianyar district has been very fast. On the one hand, the rapid rise of $L P D \mathrm{~s}$ is due the increasing demand of Balinese for rural financial institutions since the institutions have been able to meet their needs for an easy access for credit (Arsyad 2005b; Arsyad 2005). On the other hand, the provincial government of Bali and Bank BPD Bali actively support the establishment of new $L P D$ s by funds provision as an initial capital and supervision for the establishment of the LPDs. The provincial government of Bali plans to set up one $L P D$ in each of the 1,600 custom villages.

As seen in Table 1, at the end of 2001 , it was recorded that $174 L P D$ s have been established in Gianyar district, and they were spread over all of the seven subdistricts. These $L P D$ s together employ 873 employees directly. In terms of asset development, the LPDs of Gianyar have also experienced a remarkable growth. Table 1 also shows that in only two years between 1999 and 2001, total assets increased almost 2.5 times from Rp58 billion to Rp125 billion. This growth was mainly caused by the growth of loans outstanding that more than doubled from Rp36 billion in 1999 to Rp89 billion in 2001. In addition, establishment of new LPDs also has increased the total assets.

Meanwhile, its equity also more than doubled from Rp10.9 billion in 1999 to Rp25.4 billion in 2001. Equity here refers to value to invested capital (initial investment) plus retained earnings. The increasing equity resulted from the increase of retained earnings (total profit). As shown in Table 1, total profit of the $L P D$ s has increased from Rp4.4 billion in 1999 to Rp10.2 billion in 2001. In addition to the profit, the initial investment for new establishments of the LPDs also has raised the total equity.

The main activity of the $L P D \mathrm{~s}$ is lending-savings activity for mainly small-scale entrepreneurs, small traders, and farmers. The volume of loans outstanding also rapidly increases from year to year. The data in Table 1 shows that in 1999 the volume of loans outstanding was Rp36 billion and in 2001 this amount increased to Rp89 billion. Moreover, other than the volume of loans outstanding, the number of borrowers also increased from 36,454 borrowers to 49,593 borrowers in the same period.

The development indicators of $L P D$ s from deposits side are savings and time deposits. Both savings and time deposits are very high, not only in terms of the value of funds generated, but also in terms of the number of savers and depositors. Table 1 shows that the total amount of funds generated from the clients through savings and time deposits exceeded the total amount of loans outstanding in 1999 and 2001. In 1999 the generated funds from the clients were Rp45.5 billion while the total of loans outstanding were Rp36 billion. In 2001 these amount increase to Rp97 billion and Rp89 billion respectively. Table 1 also 
shows that the number of savers and depositors also exceeded the number of borrowers in 1999 and 2001. In 2001 , the number of borrowers of 49,593 was much lower than the number of savers and depositors accounts of 122,942 . These high growth of number of borrowers, outstanding loans, savings and deposits is the evidence of strong client demand.

The figures above will in turn affect the deposits to loans ratio (DLR) and savers (and depositors) to borrowers ratio. Table 1 shows that these two ratios were higher than 100 percent and the most remarkable thing is that the savers and depositors to borrowers ratio exceeded 200 percent in 1999 and 2001. This phenomenon implies that the $L P D$ s in Gianyar have succeeded in achieving their role as financial intermediaries and to enhance their outreach, which is a proxy of its positive impact on rural economic development. There are five main reasons that could explain this phenomenon (Arsyad 2005b; Arsyad 2005). Firstly, the high savers and depositors to borrowers ratio might be caused by social and cultural ties (social cohesion) between the people in a custom village and its LPDs. Secondly, the people have an easy access to reaching the $\angle P D$ since the $L P D$ is located in a custom village. Therefore, transportation cost is very low or even zero. This could also be an attractive factor for the clients to save their money in $L P D$ s. Thirdly, the $L P D$ s also apply a simple and easy procedure -both in lending and saving services- and use mobile banking techniques to reach their clients. Fourthly, the competition among financial institutions is not tight in the village level. Lastly, the growth of those figures might also be affected by the stable and growing economy of Gianyar district. Presently, Gianyar district with a population of 395,000 is one of the growth engines of Bali's provincial economy. According to Statistics of Bali Province 2001, with Gross Regional Domestic Product (GRDP) of Rp 2,307 billion, Gianyar was the fourth biggest contributor (12.16\%) to Bali provinceafter Badung district $(20.86 \%)$, city of Denpasar (19.19\%), and Buleleng district (12.19\%). Based on GRDP per capita, Gianyar was ranked third after Badung district and city of Denpasar in the same period. During Indonesian economic crisis from 1997 until 1999, the Gianyar economy still experienced a positive economic growth. Gianyar economic growth rates were 6 and 4.5 percent annually in 1997 and 2001, respectively. Its economic growth rate in 2001 was higher than Bali and national average growth rate of 3.4 and 3.3 percent per annum, respectively. According some studies (Chaves and Gonzales-Vega 1996: Franks 2000; Robinson 2001), it is argued that microfinance institutions can evolve sustainably in a stable and growing economy.

From another perspective, the rapid growth in the number of borrowers, savers, depositors, loan outstanding, savings and deposits -as has been noted earlier- is evidence of strong 
Arsyad-Assessing Factors Affecting the Repayment Rate of Microfinance Institutions

clients demand in Gianyar district. According to some interviewees ${ }^{2}$ and Oka (1999), the rapid growth is an indication that the $L P D$ s have -as financial institutions-suited to the needs of rural people and succeeded to develop a trust of them.

On the contrary, the high savings and deposits growth rates could be a burden for the $L P D$ s to pay the interest cost. To avoid this problem the $L P D \mathrm{~s}$ deposit some of their unloanable funds (excess liquidity) -at market interest rate-in Bank BPD Bali in accordance to the Bali Provincial Regulation No.8/ 2002, Article 7 (Government of Bali 2002). Table 1 shows that the LPDs' deposit in Bank BPD Bali was quite high. It was Rp20 billion in 1999, or about a half of savings plus time deposits, and Rp29 billion in 2001, or about one-third of savings plus time deposit. Besides its operational income, this large number of the $L P D$ deposits in Bank BPD Bali has also contributed the total income of the $L P D \mathrm{~s}$ and, in turn, increased its total profit from Rp4.4 billion to Rp10.2 billion in 1999 and 2001 respectively, as shown in Table 1. On the other hand, this large number of the LPDs deposit to Bank BPD Bali also indicates that the absorption capacity of rural people for credit is still limited. This condition, however, is mainly caused by the small and limited operational area of each $L P D$ which is restricted to only one custom village according to the regu- lation mentioned above (Government of Bali).

\section{Sociocultural Environment of the $L P D$ s}

Socio-cultural characteristics of an environment are also one of the important factors in the success of microfinance institutions (Chaves and Gonzales-Vega 1996; Franks 2000; Robinson 2001; Snow 1999). This section discusses the socio-cultural characteristics of the Balinese focusing on the custom village (desa adat) and banjar (hamlet) as corporate groups (social system) since it will be very useful in assessing the factors affecting the repayment rate of the $L P D$ s. As widely known and argued, some of these sociocultural factors have played a major role in the success of government programs such as family planning, small-scale industry training, and loan programs in Bali (Jayasuriya and Nehen 1989: 13; Warren 1991: 233).

In Bali, besides the administrative village (desa dinas), which is an element of government administration, Balinese also recognize the existence of custom villages. The administrative village or perbekelan was first introduced by the Dutch in the early part of the twentieth century as the basic unit of colonial government (Warren 1993: 22). The existence of administrative village in Bali and all over Indonesia

${ }^{2}$ The list of interviewees is presented in Appendix 1 
was reinforced by the Government of Republic of Indonesia through the VillageGovernmentLaw No. 5/1979. This Law sets out to create a uniform local administrative structure across Indonesia, with the stated objective of increasing the effectiveness of village administration and public participation in development policy (Warren 1991: 238). However, custom villages in Bali continued to exist as customary institutions and to function alongside their newly created administrative counterparts.

The custom village is an association of people rather than a geographic or administrative unit. Warren (1993: 20) describes the custom village as "a corporate community sharing collective descent from the original village founders, who are worshipped as deified ancestors in the classic three village temples the so called Kahyangan Tiga (The ThreeHoly Temples)." Each of the three temples has a special function and location in the village (Geertz and Geertz 1975; Hobart et al. 1996). ${ }^{3}$

There are two fundamentals differences between custom village (desa adat) and administrative village. The desa dinas boundaries are determined along administrative lines and seldom coincide with those of the custom village. The custom village leader, the so-called Bandesa Adat, is elected and custom matters are decided by the community (banjar) members in a democratic way in the custom village meeting (paruman desa). In contrast, dinas (administrative) leaders, the so-called Perbekel or Kepala Desa, are appointed by, and responsible to, higher government levels such as subdistrict and district government level. According to Nordholt (1991), in the Soeharto era, villages maintained the right to choose their Perbekel or Kepala Desa in Bali, but in practice there were several restrictions. Candidates were screened and sometimes there was pressure from above to eliminate candidates considered to be too independent or anti Golkar (state party) (Nordholt 1991).

The status of the custom village as a societal unit based on customary law was reinforced by the Bali Provincial Regulation of 1986 on the Status, Function, and Role of Custom Village in Bali (Government of Bali 1986). The custom village, as stated in article 5 of the Regulation, is a unit of societal customary law that is social and religious in nature. The village is the for-

\footnotetext{
${ }^{3}$ The first temple is Pura Puseh (Temple of Origin). This is the temple of origin in which the village community worships its purified and deified ancestors. It lies in the 'godly direction,' that is, towards the mountains and/or east of the village core. Various gods are worshipped in this temple, but the main ones are an anonymous host of deified predecessors of the present inhabitants of the village. In the centre of the village, in the intermediate area between earthly and godly activity, lies Pura Desa (Temple of Village or Great Council). This second temple is primarily concerned with the fertility of the farmland in its neighbourhood. The third temple is Pura Dalem (Temple of Death) which is usually located next to the cemetery. It lies in the direction of the sea and/or the western part of the village. This temple, in addition to being temple of death, is the temple of chthonic powers where, among other things, the deceased who are not yet fully purified are remembered.
} 
Arsyad-Assessing Factors Affecting the Repayment Rate of Microfinance Institutions

mal repository and guardian of customary law and ritual. Meanwhile, the function and role of custom village, as stated in article 6 of the Law, is to support the implementation of the development program planned by the government, especially in the religious, cultural, and social areas; and to maintain and utilize the wealth of the custom village for the welfare of the people within the village. The ratification of the Provincial Regulation of 1986 reflects the Provincial Government's concern with reinforcing the role of community institutions, grounded in customary law and practice. The consideration of the regulation states that it recognizes custom village since they have have grown and developed for centuries and contributed significantly to the livability of people in Bali.

The custom villages are usually subdivided into several banjar (hamlets) for densely populated regions (Warren 1993). However, Warren points out that in a large number of communities, especially those found in the mountain areas, banjar and custom village represent two associations covering a single bounded population. The banjar is the most basic association of people in custom villages (communities) through which religious rites, mutual aid, cultural groups, local development projects and savings and credit activities are organized within close social ties. The members of banjar comprise adult men who can prove the completeness of their identity through a female partner - usually the wife, but sometimes sister, mother, or daughter. The focus of religious, social, and economic life of the Balinese is the banjar, which effectively ${ }^{4}$ implements local custom (adat) in the name of the custom village, and organizes community life in Bali (Geertz and Geertz 1975; Hobart et al. 1996; Mabbet 1985). Arsyad (2005a and 2005b) points out that the LPDs are rooted in the community and their establishment is grounded in the customary law and practice of its people. The institutions are community financial institutions owned, managed, and used by the members of the custom village. The staff and clients of the $L P D \mathrm{~s}$, therefore, have to follow the customary rules (awig-awig) of the custom village.

There have been two important duties of the banjar (Hobart et al. 1996: 86-88; Mabbet 1985: 38-40). First, among the most important duties of the banjar is the maintenance and restitution of the ritual purity of the custom village. Each banjar has specific tasks and ritual duties to fulfill the benefit of the village temples. This indicates that the village as a religiousmagical authority is ranked above the secular autonomy of the banjar. However, banjar activities can be very mundane, for example, improving roads through community work or restoring the meetinghouse (bale banjar).

\footnotetext{
${ }^{4}$ The banjar is effective since its decisions involved the equal participation of all families and because it operates through consensus rather than confrontation (Mabbet 1985: 39).
} 
Gadjah Mada International Journal of Business, May-August 2006, Vol. 8, No. 2

The banjar is generally responsible for public institutions and even more for public welfare, which requires not only material support but also assistance in ritual matters.

Another important task of the banjar relates to social control and surveillance of the actions and behavior of the members in relation to the custom(Hobart et al. 1996). The banjar is legally permitted to impose sanctions against members who do not follow the rules (awig-awig), and fines may be incurred. Serious offences against the rules are punished by the exclusion of the wrongdoer from the banjar. This means that he/she loses his/her share of banjar ownership and the plot of land on which his/her family compound is built is withdrawn. $\mathrm{He} /$ she also loses the right, in accordance to the custom, to a funeral in the village cemetery and subsequent cremation. $\mathrm{He} /$ she becomes an outsider without security of the banjar community and must look for new life far away from their native village. In relation to the LPDs, which are owned by the custom village, these kind social of sanctions can be applied to the staff or clients who violate the rules of the financial institution, such as by corruption or failure to repay their credits properly (Oka 1999). In other words, the rules can be expected to have a positive effect on the repayment rate of the LPDs.

\section{Methodology}

\section{Data and model specification}

The fieldwork of this study was conducted in two parts, the first being from early December 2001 until the end of March 2002 and the second in March 2003. The dataset used as the basis for calculation and analysis are mainly based on financial reports of the $L P D \mathrm{~s}$ of the Gianyar district in 1999 and 2001 because of the limitations of time and other resources, and to omit the influence of Indonesian economic crisis before 1999. Hence, this study only focuses on the condition of the $L P D$ in the period of 19992001 when the economic situation of Bali was stable. The economic situation after 2001 -that might have changed- is outside the scope of this study. In addition, other related data such as the number of client data (including borrowers, savers, and depositors), the data on population and Gross Regional Domestic Product (GRDP) of Gianyar district and its subdistricts from the Central Board of Statistics of Gianyar district are also used in this analysis.

At the end of 2001, it was recorded that 174 LPDs have been established in Gianyar district and they were spread all over seven subdistricts. There are 103 LPDs located in four subdistricts which are the centre of 
Arsyad-Assessing Factors Affecting the Repayment Rate of Microfinance Institutions

Table 2. Number of LPDs in Gianyar District by Subdistricts and Economic Characteristic (2001)

\begin{tabular}{|c|c|c|c|}
\hline No. & Subdistrict & Number of LPD & Economic characteristics \\
\hline 1 & Sukawati & 26 & Handicraft industry \\
\hline 2 & Gianyar & 28 & Handicraft industry \\
\hline 3 & Ubud & 24 & Handicraft industry \\
\hline \multirow[t]{2}{*}{4} & Tegallalang & 25 & Handicraft industry \\
\hline & Subtotal (a) & (103) & \\
\hline 5 & Blahbatuh & 25 & Agriculture \\
\hline 6 & Tampaksiring & 23 & Agriculture \\
\hline \multirow[t]{2}{*}{7} & Payangan & 23 & Agriculture \\
\hline & Subtotal (b) & (71) & \\
\hline \multicolumn{2}{|c|}{ TOTAL $(\mathbf{a}+\mathbf{b})$} & 174 & \\
\hline
\end{tabular}

Source: PLPDK, Financial Report of LPD Gianyar District of Bali Province (2001)

handicraft industries (handicraft-based subdistricts) and 71 located in three agricultural-based subdistricts as shown in Table 2.

After conducting the normality test for the data using Lilliefors test ${ }^{5}$ (Coakes and Steed 1999; Keller and Warrack 2000), the results reveal that the performance indicators data are not normally distributed. Since the datasets are not normally distributed and the repayment rate is a continuous variable, an ordinary least squares model will lead to inefficient param- eters estimates, because of heteroscedasticity problem (Maddala 1983: 16). Alternatively, following Goldberger (1964), Maddala (1983) suggests the use of binomial or binary choice model $^{6}$-such as probit (or the normit model) and logit model- to overcome the problems because it uses a dummy variable (for the repayment rate) instead of a continuous variable. The probit and logit models usually give similar results and it is difficult to distinguish them statistically, since the cumulative normal distribution of

\footnotetext{
${ }^{5}$ The procedure of this test is presented in the appendices. This test is suited for this case since the population data which mean and standard deviation are unknown. A test for normality of Kolmogorov and Smirnov is not relevant to this case since it assumes that the mean and standard deviation of population is known (Keller and Warrack 2000: 614).

${ }^{6}$ These binary-choice models are regression models using discrete dependent variable and involving two or more qualitative choices. These models assume that individuals are faced with a choice between two alternatives and that their choice depends on their characteristics.
} 
Gadjah Mada InternationalJournal of Business, May-August 2006, Vol. 8, No. 2

probit model and the logistic distribution are very close to each other (Amemiya 1985: 09-310; Amemiya 1981: 1502; Maddala 1983: 23; Tabachnick and Fidell 2001: 536). However, the assumption that underlying distribution is normal makes probit analysis somewhat more restricted than logit analysis. Hence, the logit analysis is considered better than probit analysis if there are too many cases with very high or very low probabilities so that an underlying normal distribution is untenable (Tabachnick and Fidell 2001: 536). The logit model has another advantage over the probit model which is the ease of numerical calculation, as a logistic function is much easier to calculate that the cumulative normal function of the probit model (Amemiya 1981). In addition, the logit model can be used without any change even with unequal sample sizes (Maddala 1992: 330-331). For these reasons, this study estimates the model by using the logistic model (logit).

The logit model is based on the cumulative logistic probability function and is specified as (Pindyck and Rubinfeld 1991)

$$
\begin{aligned}
\mathrm{Pi}=\mathrm{F}\left(\mathrm{Z}_{\mathrm{i}}\right) & =\mathrm{F}\left(\alpha+\beta \mathrm{X}_{\mathrm{i}}\right)=\frac{1}{\mathrm{e}^{-\mathrm{zi}}} \\
& =\frac{1}{1+\mathrm{e}^{-(\alpha+\beta \mathrm{Xi})}}
\end{aligned}
$$

where $e$ represents the base of natural logarithms, which is approximately equal to 2.718. $P i$ is the probability of a certain event, given $X_{i}$. The first step to estimate the model is both sides of the model is multiplied by $1+\mathrm{e}-\mathrm{z}_{\mathrm{i}}$ to get

$$
\left(1+\mathrm{e}^{-\mathrm{zi}}\right) \mathrm{P}_{\mathrm{i}}=1
$$

Dividing by $P_{i}$, and then subtracting 1 leads to

$$
\mathrm{e}^{-\mathrm{zi}}=\frac{1}{\mathrm{P}_{\mathrm{i}}}-1=\frac{1-\mathrm{P}_{\mathrm{i}}}{\mathrm{P}_{\mathrm{i}}}
$$

By definition, however, $\mathrm{e}^{-\mathrm{zi}}=1 / \mathrm{e}^{\mathrm{zi}}$, so that

$$
\mathrm{e}^{-\mathrm{zi}}=\frac{\mathrm{P}_{\mathrm{i}}}{1-\mathrm{P}_{\mathrm{i}}}
$$

Now, by taking the natural logarithm of both sides,

$$
Z_{i}=\log \frac{\mathrm{P}_{\mathrm{i}}}{1-\mathrm{P}_{\mathrm{i}}}
$$

or

$$
\log \frac{P_{i}}{1-P_{i}}=Z_{i}=\alpha+\beta X i
$$

Since $P i$ is the probability of being the one group, and $\left(1-\mathrm{P}_{\mathrm{i}}\right)$ is the probability of being other group, the ratio $P_{i} /(1$ - $\mathrm{P}_{\mathrm{i}}$ ), known as odds ratio, is simply the odds in favor of an event A. The natural $\log$ of this odds ratio is called the logit, and therefore the model is called the logit model. $X_{i}$ is the vector of independent variables for the $i^{\text {th }}$ observation; $\alpha$ is the intercept parameter; and $\beta$ is the vector of coefficient parameters. 
Arsyad-Assessing Factors Affecting the Repayment Rate of Microfinance Institutions

The procedure of estimating coefficients is maximum likelihood techniques $^{7}$ (Amemiya 1981: 1493-1499; Tabachnick and Fidell 2001: 518), and the goal is to find the best linear combination of predictors to maximize the likelihood of obtaining the observed outcome frequencies. A positive and significant estimated coefficient would imply that an increase in the value of the particular explanatory variable is associated with an increased probability of the dependent variable taking the value one. Given the exploratory nature of the analysis, the reliance on imperfect proxies and the nonlinear relationship between the dependent and independent variables, no attempt has been made to interpret the magnitudes of the coefficients of the explanatory variables. Rather, the analysis focuses on the signs and significance of the estimated coefficients. Collinearity diagnostics are performed on each set of explanatory variable employed in the model, to ensure that multi-collinearity is not adversely affecting the estimation of the coefficients

The logit model is used to study the repayment rate (RR) of $154 L P D$ s in Gianyar district, in 2001. Since the repayment rates in this study are continuous variable, they are converted to a discrete variable. In this model, $P_{i}$ is probability of $L P D$ s having repayment rates "above" average of repayment rate of its population, $\left(1-\mathrm{P}_{\mathrm{i}}\right)$ is a probability of $L P D$ s having repayment rates "below" average of repayment rate of its population.

$\mathrm{y}_{\mathrm{i}}\left\{\begin{array}{l}1, \text { if the repaymentrate is "above" average } \\ 0, \text { otherwise }\end{array}\right.$

Hence the logit model becomes

$$
\log \frac{\operatorname{Prob}(\mathrm{RR}>\text { above })}{1-\operatorname{Prob}(\mathrm{RR}>\text { above })}=\mathrm{Z}_{\mathrm{i}}=\alpha+\beta \mathrm{X}_{\mathrm{i}}
$$

The repayment rate is expected to be influenced by a range of explanatory variables that reflect programspecific and community socioeconomic characteristics. The expected signs for the parameters coefficient are shown in Table 3 . The independent variables are as follow. First, OUTSTL is a total balance of outstanding loans of each $L P D$ (in Rupiah). The hypothesis is the higher total balance of outstanding loans of the $L P D$, the higher is its repayment rate (Sharma and Zeller 1997). This is because the greater the loan size put pressure on the borrower to reduce the delinquency rate. Second, NUMBOR is number of clients (borrowers) of each $L P D$. The hypothesis is the larger the number of clients of a microfinance institution, the lower is its repayment rate. The larger number of borrowers could raise asymmetric information problem and make monitoring and enforcing costly and less effective(Sharma and Zeller 1997).

\footnotetext{
${ }^{7}$ Maximum likelihood estimation is an iterative procedure that starts with arbitrary values of coefficients and determines the direction and size of change in the coefficients that will maximize the likelihood of obtaining the observed frequencies (Tabachnick and Fidel 2001: 518).
} 
Gadjah Mada International Journal of Business, May-August 2006, Vol. 8, No. 2

Table 3. Independent Variables and Expected Signs of Logit Model for the Repayment Rate of the LPDs

\begin{tabular}{lc}
\hline \multicolumn{1}{c}{ Independent Variable } & Expected Sign \\
Outstanding loans (OUTSTL) & + \\
Number of borrowers (NUMBOR) & - \\
Number of savers (NUMSAVER) & + \\
Number of staff (NUMSTAF) & + \\
Wealth index (WEALTH) & + \\
Dummy regions (DUMVIL) & $*$ \\
\hline
\end{tabular}

Note: $*=$ no a priori expectation for sign direction

Third, NUMSAVER is the number of savers. The hypothesis is the higher number of savers in microfinance institution, the higher its repayment rate. The number of savers (and savings) is an essential element for improving the repayment rate since savers may indicate the banking mindedness and the financial disciplines of clients (Zeller 1998: 614). Fourth, NUMSTAF is number of staff, which is measured by number of staff of each $L P D$. I hypothesize that the larger number of staff in the $L P D \mathrm{~s}$, the higher its repayment rate. It is expected that a larger number of staff in the LPDs will result in a better repayment rate, since they would be able to manage the $L P D$ s better.

Fifth, WEALTH (dummy) is a dummy variable for the wealth index of the clients. It is hypothesized that the wealth of clients has a positive and significant relationship with the repayment rate (Zeller 1998: 615). This variable equals one if the $L P D$ s located in subdistricts having GRDP per capita "above" the GRDP per capita of the district and zero when the $L P D \mathrm{~s}$ located in subdistricts having GRDP per capita "below" average of the district. Sixth, DUMVIL (dummy variable for region) is a control variable for the economic base of villages that might influence the repayment rate (Zeller 1998: 613). The hypothesis is there will be a significant relationship between the economic base of a village and the repayment rate of the $L P D$ in that village. This variable has the value of one if the $L P D$ is located in small-scaleindustries based villageand zero when it is located in agricultural based village. It is expected that the repayment rate is affected by the client's occupation, in particular, whether he or she is employed in the agricultural sector or in small-scale industry. Table 3 summarizes the independent variables and expected signs for the ordinary least square model. The specification model of the repayment rate is as follows: 
Arsyad-Assessing Factors Affecting the Repayment Rate of Microfinance Institutions

$$
\begin{aligned}
& \log \frac{\text { Prob (RR }>\text { above })}{1-\text { Prob }(\mathrm{RR}>\text { above })} \\
&=\alpha+\beta 1 \text { OUTSTL }+\beta 2 \text { NUMBOR }+ \\
& \beta 3 \text { NUMSAVER }+\beta 4 \text { NUMSTAF }+ \\
& \beta 5 \text { WEALTH }+\beta 6 \text { DUMVIL }
\end{aligned}
$$

\section{Results and Analysis}

According to Bank BPD Bali (2000), the loans portfolio of $L P D$ is classified into four categories: pass, doubtful, substandard, and loss. In this study the repayment rate refers to the ratio between the first three categories of outstanding loans divided by total outstanding loans (all four categories), and delinquent borrower ratio refers to the number of borrowers who do not repay their loans until past due relative to total borrowers. Based on the data in Table 4, the $L P D$ s within Gianyar district have a high repayment rate.

In 1999 the repayment rate was 95 percent and increased to 97 percent in

\section{Table 4. Repayment Rate of LPDs within Gianyar District of Bali Province (1999 and 2001) (means)}

\begin{tabular}{llll}
\hline Indicator & & $\mathbf{1 9 9 9}$ & $\mathbf{2 0 0 1}$ \\
\cline { 1 - 1 } \cline { 5 - 6 } & & 95 & 97 \\
\hline
\end{tabular}

Source: PLPDK, Financial Report of LPD Gianyar District of Bali Province(1999 and 2001) (computed by the author).
2001 (Table 4). Compared to the other microfinance institutions in Indonesia, these figures are quite high. ${ }^{8}$ The repayment rate of Badan Kredit Kecamatan (Subdistrict Credit Organisation) of Central Java was only 80 percent. Meanwhile, the repayment rate of the BRI Unit Desa System was estimated 95 percent (Yaron et al. 1998). In addition to a high repayment rate, its delinquent borrowers ratio was only 0.5 percent in 1999 and decreased to 0.4 percent in 2001 . Following Christen et al (1995: 3), these high repayment rate and the low delinquent borrowers ratio of the LPDs are evidences of the willingness of the clients to pay the interest rate even the interest rates are significantly above the rate of inflation.

There are four interrelating reasons that could explain the high repayment rate (Arsyad 2005b; Arsyad 2005). Firstly, in accordance with its regulation, an $L P D$ only gives loans to the clients who have their own business, such as small-scale industry entrepreneurs, farmers, or small traders. The credit should be used for productive economic activities purposes (Government of Bali 2002) . For the $L P D$ s management, it is relatively easy to identify the credit applicants whether or not they have business activities since the operational area of each $L P D$ is limited in a custom village in which most of the people know each other.

\footnotetext{
${ }^{8}$ This comparison is not intended to judge that the LPD has a better repayment rate than the others, since it was calculated in different period and the methods of calculation might be different either. Nevertheless, it is still useful as a general illustration.
} 
Gadjah Mada InternationalJournal of Business, May-August 2006, Vol. 8, No. 2

As a result, this could positively influence their repayment ability. The use of village agents, such as custom village leader in Bali, in screening potential borrowers and collecting repayment would help to mitigate the information problems that hamper the performance of microfinance institutions when lending to small entrepreneurs (Arsyad 2005b; Arsyad 2005; Chaves and Gonzales-Vega 1996; Fuentes 1996; Onchan 1992; Timberg and Aiyar 1984; Yaron 1992). In addition, by gaining access through the agent to village-level enforcement mechanisms such as social sanctions, the microfinance institution may also mitigate some of the problems it faces when collecting repayment.

Secondly, most of the borrowers are from the custom village where the $L P D$ is located. The $L P D$ s are community financial institutions which are owned, managed, and used by the members of the custom village. This embeddedness of the $L P D$ s within its local institutions has caused the clients' sense of belonging of their $L P D$ and moral obligation to help the development of their $L P D$. Moreover, in credit mechanism including screening process and contractual enforcement, the $L P D$ s management cooperates with the Board of Commissioners (Dewan Pengawas) -led by the custom village leader (Bendesa Adat)- who knows the character (reputation) of the clients well. This technique has been comparatively efficient in avoiding costly mistakes in assessing the prob- ability of loan repayment (Arsyad 2005b; Arsyad 2005).

Thirdly, the custom (social) sanctions -that can be applied in accordance with the written custom village regulations (awig-awig) - have forced the borrowers to repay their credits timely. According to the interviewees and Oka (1999: 17), the custom village regulation has been effective in overcoming the problem of delinquent borrowers or low repayment rate. Finally, the $L P D$ s staff members have a high mobility in respect to collecting loan repayments. A $L P D$ staff member visits the clients in their houses (mobile banking techniques) to collect savings deposits and loan repayments in person. This system has also forced the clients to repay their loans regularly and timely.

In summary, it could be argued that a high repayment rate of $L P D$ s is affected by practical arrangement of $L P D$ management using custom regulation which includes social norms, sanctions, and involvement of custom village leader in screening process and contractual enforcement of loan (informal institutions), regulations set up by the Central Bank (formal institutions), and the mechanism of collecting loan repayments applied by the $L P D$ s management.

As mentioned earlier, a direct logistic regression analysis was performed on the repayment rate and six predictors: outstanding loans, number of borrowers, number of savers, number of staff, wealth index, and dummy 
Arsyad-Assessing Factors Affecting the Repayment Rate of Microfinance Institutions

variable for regions. Analysis was performed using SPSS LOGIT. After deletion of 2 cases of missing values, data from $152 L P D$ s were available for analysis: $88 L P D$ s with the repayment rates (RR) above the average $R R$ of its population rate and $64 L P D$ s with RR below the average $R R$ of its population rate.

The first step in any regression analysis is to ask if the predictors, as a group, contribute to prediction of the outcome. In logistic regressions, this is the comparison of the constant-only model with the constant plus all predictors model. The test results of the full model with all six predictors against a constant-only model using Hosmer and Lemeshow test are statistically reliable, $\chi^{2}(8, N=152)=18.36, p<0.05$ $(\mathrm{p}$-calculated $=.019)$. This indicates that the predictors, as a set, reliably predict the repayment rate of the $L P D$ s. Moreover, this result also indicates that there is no multicollinearity problem (Tabachnick and Fidell 2001).
The strength of the relationship between the dependent variable and the independent variables -analogous to the $R^{2}$ measures in multiple regression-is shown by the Cox and Snell $\mathrm{R}^{2}$ and the Nagelkerke $R^{2}$ with higher values indicate greater model fit (Tabachnick and Fidell 2001: 545). Both $R^{2}$ are low, the Cox and Snell $R^{2}$ is only 0.063 and the Nagelkerke $R^{2}$ is only 0.08 . These figures indicate that only around six to eight percent of shared variance between the repayment rate and the set of predictors can be found. Hence, the gain in prediction is minimal. The model prediction success confirms that the ability of the model in predict the repayment rate are not high, even the predictors in the model is significant. The overall success rate is 65 percent (the cut value is 50 percent), with 84 percent of the $L P D$ s with the RR above average and 39 percent of the $L P D$ s with the $R R$ below average. This result also indicates that the predictors, as a set, reli-

Table 5. Logistic Regression Analysis of the Repayment Rate

\begin{tabular}{|c|c|c|c|}
\hline Variables & Coefficients & Wald test & $\begin{array}{l}\text { Significance } \\
\text { (p-value)* }\end{array}$ \\
\hline 1. Outstanding loans & .000 & .084 & .772 \\
\hline 2. Number of borrowers & .000 & .053 & .818 \\
\hline 3. Number of savers & -.001 & 2.646 & .104 \\
\hline 4. Number of staff & .004 & .001 & .972 \\
\hline 5. Wealth index & .070 & .034 & .853 \\
\hline 6. Dummy regions & .303 & .594 & .441 \\
\hline 7. Constant & .143 & .066 & .797 \\
\hline
\end{tabular}

Note: * Critical p-value is 0.05 ( $\mathrm{p}$-value $<0.05$ means significant, otherwise). 
ably distinguish the repayment rate of the $L P D$ s with the repayment rate above average and the $L P D$ s with repayment rate below average.

According to the Wald criterion, there is no statistically significant predictors influencing the repayment rate. Table 5 shows regression coefficients and Wald test for each of coefficients. The signs for four regression coefficients are as expected, but two other coefficients are not. These results are discussed below.

In methodology, outstanding loans are hypothesized to have a positive effect on the repayment rate. However, the regression coefficient of outstanding loans (OUTSTL) is insignificant ( $p$-value $>0.05)$. This means that the outstanding loans do not influence the repayment rate. The hypothesis that the greater the loan size, the greater is the probability of unwilling default (greater repayment rate) or the greater loan size puts pressure on the borrower to reduce delinquency, is not proven. Therefore, the outstanding loans do neither improve nor worsen the repayment rate in this case. The finding concurs with Sharma and Zeller's (1997) study of microfinance institutions (ASA, BRAC, and RDRS) in Bangladesh (Sharma and Zeller 1997).

Thenumber of savers and the value of savings reflect the financial discipline of the clients of a microfinance institution, as has been mentioned earlier. These factors could be expected to increase the repayment rate or to maintain a high repayment rate. How- ever, the regression coefficient of number of savers (NUMSAVR) is insignificant. This means that the number of savers does not influence their repayment rate. The result implies that the influence of the savers on improving the repayment rate is not significant. On the other hand, however, this result indicates that the financial discipline of the clients of $L P D \mathrm{~s}$ is high, as shown by their high repayment rates discussed earlier. Hence, regardless the provision of savings service, the repayment rate of the $L P D$ s remains high. Referring to Arsyad's studies (2005 and 2005b), this situation might be affected by the effectiveness of social sanctions (written in the custom village regulation) in enforcing contractual agreement between the $L P D$ s and their clients.

The regression coefficient of number of borrowers (BORROWERS) is insignificant. This means that the number of borrowers does not influence the repayment rate. The hypothesis that the larger number of borrower could cause imperfect information problems (monitoring and enforcing problem) that would in turn affect the repayment rate is not evident in this study. The $L P D$ s have intimate knowledge of their clients and rely on mechanisms of social control in screening and enforcement problems based on the shared social and religious norms of the custom village (Arsyad 2005b and 2005). As a result, client information is easily available which could eliminate the asymmetric information and adverse selection problems as a 
Arsyad-Assessing Factors Affecting the Repayment Rate of Microfinance Institutions

key problem that affects the likelihood of default of microfi-nance institution. The study by Sharma and Zeller (1997) also reveals that the number of borrowers per staff does not affect the repayment rate of micro-finance institutions in Bangladesh.

As is hypothesized earlier, the larger number of staff, the higher is the repayment rate since the larger number of staff, the higher is the $L P D$ staff's capability of monitoring and managing their clients. In this study, however, the number of staff does not have any influence on the repayment rate which is shown by the insignificant regression coefficient of number of staff (NUMSTAF). This implies that the number of current staff has been quite enough to manage the $L P D$ s. With the ratio of 67 borrowers per staff in 2001, the $L P D$ s are still able to maintain their high repayment rates.

Two dummy variables which are WEALTH and REGION do not have a significant effect on the repayment rate either. The regression coefficient of dummy variable WEALTH1 and WEALTH2 -control for GRDP per capita of subdistrict- is insignificant. This means that the wealth of the clients does not influence their repayment rate. The result shows that the wealthier clients (handicraft subdistricts) do not repay their debt any better than the poorer ones (agricultural subdistricts). Hence, in other words, the wealth of group member does not improve the repayment rate, and the capacity to repay does not matter in actual repayment performance in the case of LPDs. Theoretically, the repayment rate is a function of both capacity and willingness to repay (Norell 2001: 128). ${ }^{9}$ Accordingly, this implies that willingness to repay is the most important factor affecting the high repayment rate of $L P D$ s. Again, referring to Arsyad's studies (2005 and $2005 \mathrm{~b}$ ), this good willingness to repay might be a result from the effectiveness of social sanctions in enforcing contractual agreement between the $L P D$ s and their clients.

The regression coefficient of dummy variable REGION1 and REGION2 - control for socioeconomic conditions that may influence the repayment rate- is not significant. It means that the type of regions (handicraft based subdistricts or agricultural based subdistricts) has no influence on the repayment rate of the $L P D$ s. Hence, it can be concluded that the repayment rate of the $L P D$ s in Gianyar district is not influenced by the socioeconomic conditions of the regions. Then it could be argued that the repayment rate of $L P D$ s is directly affected by practical arrangement of $L P D$ management using custom regulation including social norms, sanctions, and involvement of

\footnotetext{
${ }^{9}$ In respect to capacity and willingness to repay, Norell (2001) classifies four types of clients: willing and able to repay, willing but unable to repay, unwilling but able to repay, and unwilling and unable to repay.
} 
Gadjah Mada International Journal of Business, May-August 2006, Vol. 8, No. 2

custom village leader in screening process and contractual enforcement of loan (informal institutions), and indirectly affected regulations set up by the Central Bank (formal institutions).

The insignificancy of all predictors in the model leads to a question of what factors do influence the repayment rate. Referring to Arsyad's studies (2005 and 2005b), it could be argued that this condition indicates that the informal institutions -such as custom regulation (social norms and sanctions), social cohesion, and the use of social mechanism in screening the credit applicants and enforcing the repayment through involvement of the custom leader- have played an important role in enforcing the willingness to repay of the clients that, in turn, results in the high repayment rate of the $L P D$ s.

Some studies (Arnott and Stiglitz 1990; Fuentes 1996; Stiglitz 1990) reveal that informal institutions tend to exploit a comparative advantage in monitoring and enforcement capacity. The primary advantage of the $L P D \mathrm{~s}-$ as a local institution- in terms of monitoring is that individuals who interact in a variety of non-market contexts tend to know each other well. They therefore may have a greater ability to monitor each other than do commercial banks. In this respect, the character-based lending system has been applied appropriately and effectively by the $L P D$ s through social mechanism.
This finding also conforms to Chaves and Gonzales-Vega's (1995) argument that social pressure from local tradition is one of the important factors affecting compliance of microfinance clients in the rural areas of Indonesia. Hence, it could be inferred that the high repayment rate of the $L P D$ s in Gianyar district of Bali has been influenced by the informal institutions.

\section{Conclusion}

An analysis of the repayment rate using quantitative approach (logistic model) indicates that the Balinese social custom, including social values, norms, and sanctions have an important influence on sustaining the high repayment rate of the $L P D$ s. This finding conforms to the previous studies using institutional approach (Arsyad 2005 b , 2005c and 2005) revealing that the high repayment rate of the $L P D \mathrm{~s}$ in Gianyar district is influenced by their institutional arrangement that based on custom regulation which includes social norms, sanctions, and involvement of custom village leader in screening process and contractual enforcement of loan (informal institutions), by regulations set up by the Central Bank (formal institutions), and the mechanism of collecting loan repayments applied by the $L P D$ s management. 
Arsyad-Assessing Factors Affecting the Repayment Rate of Microfinance Institutions

\section{References}

Adams, D. W. 1984. Are the arguments for cheap agricultural credit sound? In Adams, Dale W. and J. D. Von Pischke (editors) Undermining Rural Development with Cheap Credit. Boulder, Colorado: Westview Press.

Adams, D. W., and D. A. Fitchett (editors). 1992. Informal Finance in Low-Income Countries. Boulder, C.O.: Westview Press.

ADB. 2000. Finance for the Poor: Microfinance Development Strategy. Manila: Asian Development Bank.

Amemiya, T. 1985. Advanced Econometrics. Oxford, UK: Basil Blackwell.

Amemiya, T. 1981. Qualitative response models: A survey. Journal of Economic Literature 19 (December): 1483-536.

Arnott, R., and J. E. Stiglitz. 1990. Moral hazard and nonmarket institutions: Dysfunctional crowding out or peer monitoring. American Economic Review81 (1): 179-90.

Arsyad, L.. 2005b. An assessment of microfinance institution performance: The importance of institutional environment. Gadjah Mada International Journal of Business 7 (3): 391-427.

Arsyad, L.. 2005c. An assessment of performance and sustainability of microfinance institutions: A case study of village credit institutions of Gianyar, Bali, Indonesia. Unpublished Ph.D. Thesis. Adelaide, Australia: School of Business Economics, Flinders University.

Arsyad, L. 2005. Institutions do really matter: Important lessons from village credit institutions of Bali. Journal of Indonesian Economy and Business 20 (2): 105-19.

Bank Indonesia. 1997. Circular Letter of Bank Indonesia No.30/3/UPPB. Jakarta, Indonesia: Bank Indonesia.

Bennett, L. 1998. Combining social and financial intermediation to reach the poor: The necessity and dangers. In Kimenyi, M. S., R. C. Wieland, and J. D. Von Pischke (editors) Strategic Issues in Microfinance. Aldershot, England: Ashgate.

Chaves, R. A., and C. Gonzales-Vega. 1996. The design of successful rural financial intermediaries: Evidence from Indonesia. World Development 24 (1): 65-78.

Christen, R. B., E. Rhyne, and R. Vogel. 1995. Maximizing the outreach of microenterprise finance: the emerging lessons of successful programs. Focus Note 2. Washington, D.C.: CGAP.

Christen, R. P. 1998. Keys to financial sustainability.In Kimenyi, M. S., R. C. Wieland, and J. D. Von Pischke (editors) Strategic Issues in Microfinance. Aldershot, England: Ashgate.

Coakes, S. J., and L. G. Steed. 1999. SPSS: Analysis without Anguish. Brisbane: John Wiley and Sons.

Franks, J. R. 2000. Macroeconomic stabilization and the microenterpreneur. Journal of Microfinance 2 (1): 69-89.

Fuentes, G. A. 1996. The use of village agents in rural credit delivery. The Journal of Development Studies 33 (2): 188-209. 
Gadjah Mada International Journal of Business, May-August 2006, Vol. 8, No. 2

Geertz, H., and C. Geertz. 1975. Kinship in Bali. Chicago: The University of Chicago Press.

Ghate, P. 1988. Informal credit markets in Asian developing countries. Asian Development Review 6 (1): 64-85.

Government of Bali (Provincial). 1988. The Bali Provincial Regulation No. 2/1988 on Village Credit Institutions.

Government ofBali (Provincial). 1986. The Bali Provincial Regulation No. 6/1986 on the Status, Function, and Role of Custom Village.

Government of Bali (Provincial).. 2002. The Bali Provincial Regulation No. 8/2002 on Village Credit Institutions.

Hobart, A., U. Ramseyer, and A. Leemann. 1996. The Peoples of Bali. Oxford: Blackwell Publishers.

Jayasuriya, S., and I. K. Nehen. 1989. Bali: economic growth and tourism. In Hal Hill (editor) Unity and Diversity: Regional Economic Development in Indonesia since 1970. New York: Oxford University Press, Inc.

Keller, G. and B. Warrack. 2000. Statistics for Management and Economics $\left(5^{\text {th }} \mathrm{ed}.\right)$. Albany: Duxbury.

Ledgerwood, J. 1999. Microfinance Handbook: An Institutional and Financial Perspective. Washington, D.C.: The World Bank.

Mabbet, H. 1985. The Balinese. Wellington, New Zealand: January Books.

Maddala, G. S. 1983. Limited-Dependent and Qualitative Variables in Econometrics. Cambridge: Cambridge University Press.

Morduch, J. 1999. The microfinancepromise. Journal of Economic Literature 37 (December): 1569-614.

Morduch, J. 2000. The Microfinance schism. World Development 28 (4): 617-29.

Nordholt, H. Schulte. 1991. State, Village, and Ritual in Bali: A historical perspective. Amsterdam: VU University Press.

Norell, D. 2001. How to reduce arrears in microfinanceinstitutions. Journal of Microfinance 3 (1): 115-30.

Oka, I. G. N. 1999. Peranan awig-awig desa adat dalam operasional Lembaga Perkreditan Desa (LPD) (The role of awig-awig - custom village regulation- in operational of LPD. Mimeo. Majelis Pembina Lembaga Adat (Forum for the Development of Custom Institutions) Propinsi Daerah Tingkat I Bali.

Onchan, T. 1992. Informal rural finance in Thailand. In Adams, Dale W., and D. A. Fitchett (editors) Informal Finance in Low-Income Countries. Boulder, Colorado: Westview Press.

Otero, M. 1999. Bringing development back, into microfinance. Journal of Microfinance 1 (1): 8-19.

Pindyck, R. S., and D. L. Rubinfeld. 1991. Econometric Models and Economic Forecasts ( $3^{\text {rd }}$ ed.). New York: McGraw-Hill, Inc. 
Arsyad-Assessing Factors Affecting the Repayment Rate of Microfinance Institutions

Robinson, M. S. 2001. The Microfinance Revolution: Sustainable Finance for the Poor. Washington, D.C.: The World Bank.

Scapens, R. W. 1990. Researching management accounting practice: The role of case study methods. British Accounting Review 22: 259-81.

Sharma, M., and M. Zeller. 1997. Repayment performance in grouped-based credit programs in Bangladesh: An empirical analysis. World Development 25 (10): 173142.

Snow, D. 1999. Microcredit: An institutional development opportunity. International Journal of Economic Development 1 (1): 65-79.

Stiglitz, J. E. 1990. Peer monitoring and credit markets. The World Bank Economic Review 4 (3): 351-66.

Tabachnick, B. G., and L. S. Fidell. 2001. Using Multivariate Statistics $\left(4^{\text {th }} \mathrm{ed}\right)$. Boston: Allyn and Bacon.

Timberg, T. A., and C. V. Aiyar. 1984. Informal credit markets in India. Economic Development and Cultural Change 33 (6): 43-59.

Wai, U. T. 1992. What havewe learned about informal finance in three decades? In Adams, D. W., and D. A. Fitchett (editors) Informal Finance in Low-Income Countries. Boulder, Colorado: Westview Press.

Warren, C. 1993. Adat and Dinas: Balinese Communities in the Indonesian State. Oxford: Oxford University Press.

Warren, C. 1991. Adat and dinas: Village and state in contemporary Bali. In Geertz, H. (editor) State and Society in Bali. Leiden: KITLV Press.

Woolcock, M. J. V. 1999. Learning from Failures in Microfinance: What unsuccessful cases tell us about how group-based programs work. The American Journal of Economics and Sociology 58 (1): 17-22.

Yaron, Y. 1992. Successful rural finance institutions. World Bank Discussion Papers. Washington, D.C.: The World Bank.

Yaron, Y. 1994. What makes rural finance institutions successful? The World Bank Research Observer 9 (1): 49-70.

Yaron, Y., Mc. D. Benjamin, and S. Charitonenko. 1998. Promoting efficient rural financial intermediation. The World Bank Research Observer 13 (2): 147-70.

Yin, R. K. 2003. Case Study Research: Design and Methods. Sage: Nebury Park.

Zeller, M. 1998. Determinants of repayment performance in credit groups: The role of program design, intragroup risk pooling, and social cohesion. Economic Development and Cultural Change 46 (3): 599-620. 
Gadjah Mada International Journal of Business, May-August 2006, Vol. 8, No. 2

\section{Appendices}

\section{List of Interviewees*}

\begin{tabular}{|c|c|c|c|}
\hline No. & Name & Position & Date of Interview \\
\hline 1 & Bagus Sara & Provincial Government Officer & 6 February 2002 \\
\hline 2 & Gusti Arya & Provincial Government Officer & $\begin{array}{l}6 \text { February } 200220 \\
\text { February } 2003\end{array}$ \\
\hline 3 & Bagus Sana & Bank BPD Bali Officer & $\begin{array}{l}7 \text { February } 200221 \\
\text { February } 2003\end{array}$ \\
\hline 4 & Wayan Weka & Bank BPD Bali Officer & $\begin{array}{l}7 \text { February } 2002 \\
21 \text { February } 2003\end{array}$ \\
\hline 5 & Nyoman Awan & Chairman of LPD Talepud & $7 \& 8$ February 2002 \\
\hline 6 & Made Dana & Chairman of LPD Mas & 21-23 February 2003 \\
\hline 7 & Ketut Awan & Chairman of LPD Kerta & $25 \& 26$ February 2003 \\
\hline 8 & Wayan Jana & Member of Commissioner Board of LPD Mas & 23 February 2003 \\
\hline 9 & Gde Dana & Chief of Commissioner Board of LPD Kerta & $25 \& 26$ February 2003 \\
\hline 10 & Ktut Empu & LPD client & 22 February 2002 \\
\hline 11 & Wayan Elin & LPD client & 23 February 2002 \\
\hline 12 & Wayan Arsha & LPD client & 22 February 2002 \\
\hline
\end{tabular}

*Name of interviewees are disguised

\section{Procedure of conducting Lillifors Test}

The procedure of this test is taken from Keller \& Warrack (2000, p.614-617) and Coakes $\&$ Steed (2001, p.35). The procedure as follows:

Suppose a cumulative distribution function is defined as

$$
\mathrm{F}(\mathrm{x})=\mathrm{P}(\mathrm{X} \leq \mathrm{x})
$$

The tables of cumulative binomial and Poisson distributions provide values for

$$
\mathrm{P}(\mathrm{X} \leq \mathrm{x})=\sum_{\mathrm{X}=0}^{\mathrm{P}} \mathrm{P}(\mathrm{x})
$$

for several values of $k$.

The sample cumulative distribution function, $S(x)$, is defined as the proportion of sample values that are less than or equal to $x$. The mean $(x)$ and $s$ are calculated from the data. Then we define the test statistic $D$ as the largest absolute difference between $\mathrm{S}(\mathrm{x})$ and $F(x)$. That is,

$$
\mathrm{D}=\max |\mathrm{F}(\mathrm{x})-\mathrm{S}(\mathrm{x})|
$$


Arsyad-Assessing Factors Affecting the Repayment Rate of Microfinance Institutions

Then we test the hypotheses

$\mathrm{H}_{0}$ : The data are normally distributed

$\mathrm{H}_{1}$ : The data are not normally distributed

Suppose $\alpha=0.05$ (level of significance for testing these hypotheses) or based on the level of significance a and the sample size we can find the critical value of $D$ from the Lillifors table. When the significance level is greater than 0.05 or $D$-calculated is greater than $D$ critical value, then normality is assumed.

3. Computer Results of Logistic Analysis

Case Processing Summary

\begin{tabular}{|c|c|c|c|}
\hline Unweighted Cases $^{a}$ & & $\mathbf{N}$ & Percent \\
\hline \multirow[t]{3}{*}{ Selected Cases } & Included in Analysis & 152 & 98.7 \\
\hline & Missing Cases & 2 & 1.3 \\
\hline & Total & 154 & 100.0 \\
\hline Unselected Cases & & 0 & .0 \\
\hline Total & & 154 & 100.0 \\
\hline
\end{tabular}

${ }^{a}$ If weight is in effect, see classification table for the total number of cases

\section{Dependent Variable Encoding}

\begin{tabular}{cc}
\hline Original Value & $\frac{\text { Internal Value }}{0}$ \\
0 & 0 \\
1 & 1 \\
\hline
\end{tabular}

Catgegorical Variables Codings

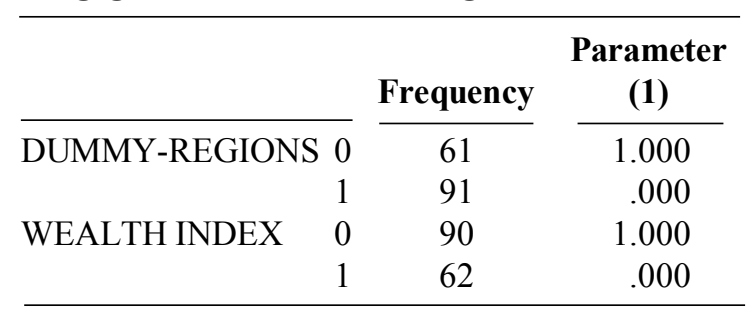

Block 0: Beginning Block

Classification Table Tab $^{\mathrm{a}, \mathrm{b}}$

\begin{tabular}{|c|c|c|c|c|}
\hline & \multirow[b]{3}{*}{ Observed } & \multicolumn{3}{|c|}{ Predicted } \\
\hline & & \multicolumn{2}{|c|}{ BI-REPAYMENT-RATE } & \multirow{2}{*}{$\begin{array}{c}\text { Percentage } \\
\text { Correct }\end{array}$} \\
\hline & & $\mathbf{0}$ & 1 & \\
\hline Step 0 & BI-REPAYMENT-RATE & 0 & 88 & 100.0 \\
\hline
\end{tabular}


Gadjah Mada InternationalJournal of Business, May-August 2006, Vol. 8, No. 2

Variables in the Equation

\begin{tabular}{llllllll}
\hline Step 0 & Constant & $\frac{\text { B }}{-.318}$ & $\frac{\text { S.E. }}{.164}$ & $\frac{\text { Wald }}{3.758}$ & $\frac{\text { df }}{1}$ & $\frac{\text { Sig. }}{.053}$ & $\frac{\text { Exp (B) }}{.727}$ \\
\hline
\end{tabular}

Variables not in the Equation ${ }^{\mathrm{a}}$

\begin{tabular}{|c|c|c|c|c|c|}
\hline & & & Score & df & Sig. \\
\hline \multirow[t]{6}{*}{ Step 0} & Variables & OUTS2001 & 4.045 & 1 & .044 \\
\hline & & BORROWER & 4.131 & 1 & .042 \\
\hline & & SAVERS & 6.849 & 1 & .009 \\
\hline & & NSTAFF & 3.945 & 1 & .047 \\
\hline & & WEALTH(1) & .001 & 1 & .972 \\
\hline & & DUMMY(1) & .053 & 1 & .819 \\
\hline
\end{tabular}

${ }^{a}$ Residual Chi-Squares are not computed because of redundancies

Block 1: Method= Enter

Omnibus Tests of Model Coefficients

\begin{tabular}{|c|c|c|c|c|}
\hline \multirow{4}{*}{ Step 1} & & Chi-Square & df & Sig. \\
\hline & Step & 9.842 & 6 & .131 \\
\hline & Block & 9.842 & 6 & .131 \\
\hline & Model & 9.842 & 6 & .131 \\
\hline
\end{tabular}

Model Summary

\begin{tabular}{|c|c|c|c|}
\hline Step & $\begin{array}{c}-2 \text { Log } \\
\text { likelihood }\end{array}$ & $\begin{array}{l}\text { Cox and Snell } \\
\text { R Square }\end{array}$ & $\begin{array}{c}\text { Nagelkerke } \\
\text { R Square }\end{array}$ \\
\hline 1 & 197.070 & .063 & .084 \\
\hline
\end{tabular}

Hosmer and Lemeshow

\begin{tabular}{lllll}
\hline Step & $\frac{\text { Chi-Square }}{1}$ & $\frac{\text { df }}{18.357}$ & 8 & Sig. \\
& $\frac{8}{1}$ & & 0.19
\end{tabular}


Arsyad - Assessing Factors Affecting the Repayment Rate of Microfinance Institutions

Contigency Table for Hosmer and Lemeshow Test

\begin{tabular}{|c|c|c|c|c|c|c|}
\hline \multirow[b]{2}{*}{ Step } & & \multicolumn{2}{|c|}{$\begin{array}{c}\text { BI-PAYMENT-RATE } \\
=0\end{array}$} & \multicolumn{2}{|c|}{$\begin{array}{c}\text { BI-PAYMENT-RATE } \\
=1\end{array}$} & \multirow[b]{2}{*}{ Total } \\
\hline & & Observed & Expected & Observed & Expected & \\
\hline \multirow[t]{10}{*}{1} & 1 & 10 & 12.500 & 5 & 2.500 & 15 \\
\hline & 2 & 13 & 10.388 & 2 & 4.612 & 15 \\
\hline & 3 & 11 & 9.566 & 4 & 5.434 & 15 \\
\hline & 4 & 10 & 9.069 & 5 & 5.931 & 15 \\
\hline & 5 & 11 & 8.690 & 4 & 6.310 & 15 \\
\hline & 6 & 4 & 8.210 & 11 & 6.790 & 15 \\
\hline & 7 & 8 & 7.858 & 7 & 7.142 & 15 \\
\hline & 8 & 10 & 7.491 & 5 & 7.509 & 15 \\
\hline & 9 & 3 & 7.017 & 12 & 7.983 & 15 \\
\hline & 10 & 8 & 7.211 & 9 & 9.789 & 17 \\
\hline
\end{tabular}

\section{Classification Table ${ }^{a}$}

\begin{tabular}{|c|c|c|c|c|c|}
\hline & \multirow{2}{*}{\multicolumn{2}{|c|}{ Observed }} & \multicolumn{2}{|c|}{ BI-REPAYMENT-RATE } & $\begin{array}{c}\text { Percentage } \\
\text { Correct }\end{array}$ \\
\hline \multirow{4}{*}{ Step 1} & & & $\mathbf{0}$ & 1 & \\
\hline & BI-PAYMENT-RATE & 0 & 74 & 14 & 84.1 \\
\hline & & 1 & 39 & 25 & 39.1 \\
\hline & Overall Percentage & & & & 65.1 \\
\hline
\end{tabular}

${ }^{a}$ The cut value is .500 